\title{
The impact of the futures market on spot volatility: an analysis in Turkish derivatives markets
}

\author{
H. Baklaci \& H. Tutek \\ Izmir University of Economics, Turkey
}

\begin{abstract}
The derivatives market in Turkey has been in operation since February 2005. This paper examines the impact of future trading on spot volatility by using Istanbul Stock Exchange 30 (ISE 30) Index future contracts which represent the most frequently traded future contracts in Turkish derivatives market.

The main objective of this paper is to investigate whether the existence of future markets in Turkey has improved the rate at which new information is impounded into spot prices and have any persistence effect.

The results gathered from the study indicate that even though it has been in operation for a short period of time, the futures market in Turkey has significantly increased the rate at which new information is transmitted into spot prices and that it has reduced the persistence of information and volatility in underlying spot market resulting in improved efficiency.

The results of this study have also some important implications for policy makers discussed in the final section of this paper.

Keywords: derivatives market, volatility, spot market, GARCH.
\end{abstract}

\section{Introduction}

There has been an ongoing debate on the impact of derivative markets on spot markets in terms of volatility, information flow, destabilizing spot markets and their speculative effects. Majority of the studies exploring the above impacts have been conducted on the developed markets, and particularly on U.S. (see for example, Board et al. [2]; Edwards [12]). On the other hand, there are only a few researches on emerging markets such as South Korea, India and Taiwan. (see for example Ryoo and Smith [18]; and Nath [16]). 
However, this issue is even more important for the developing countries for the following reasons:

- Previous studies conducted on the developed markets have documented that futures markets have contributed to the efficiency of spot markets because of their impact on rapid impounding of information into prices. In previous studies it is observed that financial markets in the developing countries have been less efficient. Accordingly, it is crucial to examine whether futures trading has any effect on increasing the efficiency of spot markets in developing countries and whether the initiation of futures trading has a significant impact on price discovery in these markets.

- On the other hand, some studies revealed that (see for example Butterworth [16]), in case the futures market exerts a destabilizing influence on spot markets through speculative trading, then there should be some policy-making implications for governmental authorities.

- Turkey has been and will be one of the most appealing emerging markets in the near future for the institutional investors particularly for foreign investors. As solid evidence, the share of foreign investors in ISE (Istanbul Stock Exchange) has increased to 67\% in 2005 (Istanbul Stock Exchange Statistics). Foreign direct investment has also increased in recent years, particularly in 2005 exceeding $\$ 9$ billion (Turkish Central Bank, Balance of Payments 2005). In addition, being a candidate state to join EU with its rapid economic growth in the past few years, Turkey is considered to be one of the 'rising stars' for foreign investors in the near future. In this respect, as being one of the latest derivative market initiated in February 2005, the role of futures trading in Turkey and its impact on spot markets are crucial issues to be investigated.

Therefore, the objective of this study is to investigate whether the existence of future trading improve the rate at which new information is impounded into spot prices and have a persistence effect and also to determine whether the introduction of future trading has a significant impact on price discovery in the Turkish spot market.

The methodology used attempts to determine whether spot price volatility changes after the initiation of future trading.

\section{Literature review}

The previous literature includes various studies debating on how the introduction of derivatives market, particularly the futures market, has affected the volatility of associated spot markets. The majority of these studies has examined this effect by using stock indices and has reached mixed results. 
One set of results gathered from these studies has concluded that the introduction of derivatives market had no effect or sometimes even decreased the spot market volatility. This result has been mainly attributed to the fact that derivatives market has increased the speed at which the information or news is impounded into spot prices. Thus, the proponents of this argument further claimed that the initiation of derivatives market has contributed to the efficiency of spot markets.

On the other hand, some studies have reached completely opposite results signifying that the derivatives market led to an increased volatility in underlying spot markets. These studies have associated this result to the existence of large speculative trading and activity, which in turn was claimed to destabilize and amplify the volatility in spot markets.

In the rest of this section, some of the selected studies including the controversial findings mentioned above will be discussed.

Holmes [15] has studied the impact of future trading on spot volatility using FTSE Index and Generalized Autoregressive Conditional Heteroskedasticity (GARCH from now on) methodology. He has proposed that the post futures volatility is less than pre futures in FTSE Index suggesting that the future trading increases the rate at which information is impounded into prices. He has also argued that the future trading has reduced the persistence of information flowing to underlying spot market.

Bologna and Cavallo [4] has reached similar results using GARCH modelling in Italian markets. Like Holmes, they have argued that the futures market has decreased spot market volatility by augmenting the speed at which the news is impounded into spot prices leading to increased market efficiency.

Two studies investigating the impact of futures trading on spot volatility in Indian market have come up with similar results. Nath [16] and Gupta and Kumar [14] have examined the impact of futures trading in Nifty and Nifty Junior indices and both have found that stock market volatility has declined after the introduction of futures markets in India.

Edwards [12] using a larger dataset including S\&P 500 Index, Value Line Index, T-Bills and Eurodollar Time Deposits has investigated the change in asset price volatility following the derivatives markets. Likewise, he has also claimed that the introduction of futures has improved the speed and quality of information flowing to the spot market contributing to the spot market efficiency.

As another advocate of the same argument, Shenbagaraman [19] has deduced the fact that derivatives had no significant impact on spot market volatility, and that the persistence of information has diminished after derivatives resulting in more efficient spot markets.

In contrast to the findings of above studies, various researches have alleged that the introduction of derivatives market has augmented the volatility in underlying spot markets. Strikingly, some of the researchers have allied this outcome with the existence and volume of speculative activity in derivatives markets and thus have asserted the destabilizing impact of derivatives market on spot markets. On the contrary, some researchers have related the volatility 
increase in spot market to the increased efficiency arising from the faster transmission of information from derivatives market to underlying spot market.

As a recent study, Ryoo and Smith [18] for instance have examined the impact of futures trading on spot Market in Korea. Their results signified that the future market in Korea has increased spot market volatility but also has increased the speed at which new info is impounded into spot prices leading to similar deductions as the supporters of counter arguments.

Using Mid250 future contracts, Butterworth [6] has gathered similar results arguing that the increase and persistence in volatility after futures trading could be adhered to the illiquidity of Mid250 contract. Antoniu and Holmes [1] and Chiang and Wang [10] have observed the same patterns for FTSE-100 Index and Taiwanese markets, respectively. Antoniu and Holmes have also acknowledged that the nature of volatility has not changed post-futures for FTSE-100 index following the futures trading.

Unlike many other researches utilizing GARCH model and daily closing prices Chiang and Wang [10], have tested the volatility impact by utilizing GJR model and by using high-low prices to proxy for the intraday volatility. Their results, have also displayed an increased volatility in Taiwanese market subsequent to futures trading.

Employing a larger sample, $\mathrm{Yu}$ [21] has detected volatility transmission between futures and spot markets for USA, France, Japan, Australia, UK, Hong Kong and has pointed out that the spot market volatility increases after stock futures in all countries except UK and Hong Kong.

\section{Empirical analysis}

The empirical analysis consist of three parts: First, the model used for testing the impact of futures market on spot volatility will be discussed followed by the explanation of data specifications. Finally, the results obtained from the analysis will be discussed along with their implications.

\subsection{Methodology}

The impact of futures trading on the underlying spot market can be examined by isolating price volatility peculiar to the underlying spot market by removing the impact of general market wide volatility. In order to capture the market wide volatility and isolate the market specific volatility on which futures contract is written, the spot price changes (returns) are regressed on a proxy variable for which there is no related futures contract by utilizing the following model [22]:

$$
\begin{aligned}
& S P C_{t}=a_{0}+a_{1} E M I C_{t}+\varepsilon_{t} \\
& \varepsilon_{t}=N\left(0, h_{t}\right)
\end{aligned}
$$


where

$$
S P C_{t}=\text { spot price change in period } \mathrm{t}(\text { ISE 30), }
$$

$E M I C_{t}=$ Price change in market proxy variable in period t (MSCI Emerging Market Index),

$$
\varepsilon_{t}=\text { error term representing unexplained price changes }
$$

The above model is used to isolate price volatility peculiar to the spot market underlying futures by removing the impact of global market wide volatility in which MSCI Emerging Market Index is used to proxy global market wide volatility. Thus, the error term captures the impact of factors specific to the futures market and variance of $\varepsilon_{t}$ proxies price volatility specific to the futures market.

There are two major reasons for selecting MSCI Emerging Market Index as a proxy:

a) There is no futures contract written on MSCI Emerging Market Index and it also includes Turkish Stock Market. Besides, by the increased effect of globalisation, the capital and information flow has amplified between emerging markets reflecting a higher correlation .

b) A diagnostic test was made by regressing ISE30 on MSCI Emerging Market Index and the results of the regression are provided in Table 1. The results of the regression further support the argument that MSCI Emerging Market Index can be postulated as a good proxy since the coefficient parameter for MSCI Emerging Market Index (0.904) is close to unity and the R-squared as well as F-statistics for the model are quite high.

The error terms from Equation 1 representing market specific volatility for ISE30 are further analysed by the following GARCH representation :

$$
h_{t}=\alpha_{0}+\alpha_{1} \varepsilon_{t-i}^{2}+\beta_{1} h_{t-i}
$$

In Equation (2), $\alpha_{1}$ represents the impact of new information and $\beta_{1}$ represents the persistence effect of information. Thus, the parameters in Equation (2) in the pre and post futures trading allows us to discover how futures trading has impacted the underlying spot market volatility and to what extent. Thus, an increase in $\alpha_{1}$ in post-futures period proposes that news is impounded into prices more rapidly following the futures trading. Accordingly, a decrease in $\alpha_{1}$ in post-futures period implies a slower information transmission into prices throughout the post-futures period. Similarly, a decline in $\beta_{1}$ specifies that information have a less persistent effect on price changes whereas an increase in $\beta_{1}$ signifies higher persistence. Thus, $\alpha_{1}$ and $\beta_{1}$ parameters in Equation 2 for the pre and post-futures period would not only allow determining whether there 
is a marked change in spot price volatility following the futures market but also allow determining whether the changes in volatility are due to more rapid impounding of information or by the destabilizing speculation effect which increases persistency of volatility and information transmission.

Table 1: Diagnostic regression results. (ISE30 $=$ Dep. Variable, MSCI Emerging Market Index $=$ Independent Variable. t-statistics are provided in parentheses.)

\begin{tabular}{ll}
\hline & Coefficient \\
Intercept & 0.126 \\
& $(1.778)$ \\
MSCI Em. Market Index & $0.904 * * *$ \\
& $(10.982)$ \\
F statistics & 120.62 \\
& \\
R-squared & 0.197 \\
Observations & 493 \\
\hline
\end{tabular}

*** Significant at $1 \%$ level.

\subsection{Data}

The daily closing price indexes of ISE30 and MSCI Emerging Market Index for the period February 2004 to February 2006 are used to examine the impact of futures trading. In estimating Equation 1, the daily price changes are used to achieve stationarity. The data for ISE30 are gathered from www.analiz.com, an online financial data site and the data for MSCI Index are obtained from MSCI website. After excluding non-trading days for both indices and matching dates for both datasets, the final sample includes 493 observations. The whole sample is further segregated into two sub samples: The pre-futures period and postfutures spanning from February 2005 to February 2006, which includes 243 observations. (Due to the limited number of observations and data for the post-futures period, the pre-futures period observations were limited to one-year data to achieve consistency in the number of observations.)

\subsection{Results}

The descriptive statistics for the daily changes in ISE30 and MSCI Emerging Market Index for the pre and post-futures periods are provided in Table 2. As observed from Table 2, the mean and standard deviation of daily price changes exhibit similar changes for both indices. Particularly, while the mean of daily returns have increased for post-futures period for both indices, the standard 
deviation of both indices have declined in the same period indicating that post-futures volatility is lower for both indices for the post-futures period. The skewness parameters for both indices, particularly for MSCI Index reveal that daily price changes do not conform to a normal distribution.

Table 2: Descriptive statistics of return changes in ISE 30 and MSCI Emerging Market Index.

\begin{tabular}{llllllll}
\hline \multicolumn{7}{c}{ ISE 30 } & \multicolumn{5}{c}{ MSCI } \\
\hline Period & $\mathrm{N}$ & Mean & Std.Dev. & Skewness & Mean & Std.Dev. & Skewness \\
Pre-futures & 250 & 0.1958 & 1.8009 & -0.0851 & 0.0495 & 0.9175 & -0.9621 \\
$\begin{array}{l}\text { (Feb. 2004- } \\
\text { Feb.2005) }\end{array}$ & & & & & & & \\
$\begin{array}{l}\text { Post-futures } \\
\text { (Feb. 2005- }\end{array}$ & 243 & 0.21 & 1.6788 & -0.2605 & 0.1225 & 0.7862 & -0.4441 \\
$\begin{array}{l}\text { Feb. 2006) } \\
\text { Whole }\end{array}$ & & & & & & & \\
sample & 493 & 0.2146 & 0.0772 & -0.0752 & 0.1133 & 0.8571 & -0.4975 \\
\hline
\end{tabular}

The volatility impact of futures can be further analysed by examining the GARCH parameters in Table 3 obtained by estimating Equation 1 and 2 for both sub sample periods.

Table 3: $\quad$ GARCH estimations.

\begin{tabular}{|c|c|c|c|c|c|}
\hline Period & $a_{0}$ & $a_{1}$ & $\alpha_{0}$ & $\alpha_{1}$ & $\beta_{1}$ \\
\hline $\begin{array}{l}\text { Pre-futures } \\
\text { (Feb. 2004- } \\
\text { Feb.2005) }\end{array}$ & $\begin{array}{l}0.1624 \\
(1.51)\end{array}$ & $\begin{array}{l}0.6743 \\
(5.76)^{* * *}\end{array}$ & $\begin{array}{l}0.2665 \\
(0.60)\end{array}$ & $\begin{array}{l}0.0586 \\
(1.17)\end{array}$ & $\begin{array}{l}0.8471 \\
(4.35)^{* * *}\end{array}$ \\
\hline $\begin{array}{l}\text { Post-futures } \\
\text { (Feb. 2005- } \\
\text { Feb. 2006) }\end{array}$ & $\begin{array}{l}0.0595 \\
(0.67)\end{array}$ & $\begin{array}{l}1.2283 \\
(10.92)^{* * *}\end{array}$ & $\begin{array}{l}1.573 \\
(2.54)^{* *}\end{array}$ & $\begin{array}{l}0.1615 \\
(1.65)^{*}\end{array}$ & $\begin{array}{l}0.0032 \\
(0.01)\end{array}$ \\
\hline
\end{tabular}

The results from the regression equation (Equation 1) and GARCH estimations (Equation 2) for each sub-period are provided in Table 3. The results are mixed in the sense that, even though $\alpha_{0}$ and $\alpha_{1}$ are statistically insignificant for the pre futures period, the same parameters turn out to be significant for the 
post-futures period. Conversely, persistence parameter $\left(\beta_{1}\right)$ is significant for the pre-futures period and insignificant for the post-futures period.

Likewise, there is a marked increase in the news coefficient $\left(\alpha_{1}\right)$ and a marked decrease in persistence parameter $\left(\beta_{1}\right)$ after the futures trading. These results imply that the existence of futures market has increased the rate at which new information is incorporated into underlying spot prices and a fall in the persistence of information. These results are consistent with the findings from most of the other studies on this topic suggesting that the futures market improves the efficiency of spot markets by a faster transmission from futures to spot market and that the futures market has a stabilizing impact on the Turkish stock market. These results also suggest that the price discovery occurs first in futures market for the Turkish stock market. However, these findings have to be further analyzed but since the futures exchange in Turkey was established in February 2005, data for the post-futures period is limited to only one year.

These results also have some vital implications for policymakers in Turkey. Firstly, commencing from 2006, government has imposed $15 \%$ capital gains tax on the majority of marketable securities traded in Turkish financial markets. However, the capital gains from futures trading has been excluded from this tax burden to encourage trading since the volume of trading was considered to be thin for the derivatives market. In this respect, the results of this study also assert that policymakers should provide similar incentives such as reducing the minimum trading size for Turkish derivatives market because of its major contribution to the efficiency of underlying spot markets.

Secondly, controversial to some of the findings in other emerging markets, the results of this particular study show no destabilizing effect of futures market on spot market in Turkey arising from speculative trading. However, because of the limited data for the post-futures period at the time, the results might be subject to a sampling bias. Thus, the authorities should still monitor the speculative movements in Turkish derivatives market for their possible destabilizing effect on underlying spot markets for future periods. In this regard, failure to inspect the causes of any possible changes in derivatives market might lead to inapt policy recommendations for the regulation of futures trading.

\section{Conclusion}

Since its inception in February 2005, the trading volume and interest of investors in Turkish derivatives exchange has been steadily increasing. This paper examines the impact of futures trading on the underlying spot market volatility in Turkish stock market by using ISE30, a stock index comprised of 30 large size firms in Turkey, on which future contracts are written and traded. The impact of futures markets is investigated by separating the whole sample into two sub periods that contain pre and post-futures trading periods.

As of this date, this is the first study that examines the impact of futures market on spot market in Turkey. Thus, the results obtained from this study are 
considered to have some important inferences for further study on this topic in Turkish financial markets.

The evidence gathered from this study demonstrate that despite its short history, the existence of futures market has significantly improved the rate at which new information is impounded into spot prices and has reduced the persistence of information and volatility in underlying spot market resulting in improved efficiency.

The results of this study have also some important implications for policy makers highlighting the fact that the incentives for the futures market should be strengthened because of its constructive effect on the underlying spot markets. However, these results must also be analyzed very cautiously. Since the sample for the post-futures period for this study cover only one year span, a possible rise in the speculative trading in the derivatives market for the future periods might have a detrimental influence on the underlying spot markets by their potential destabilizing effect. Thus, policy-making authorities should closely monitor the existence of speculative trading activity.

\section{References}

[1] Antoniou, A., \& Holmes, P. "Futures trading, information and spot price volatility: evidence for the FTSE-100 Stock Index Futures contract using GARCH.“, Journal of Banking \& Finance, 19 (1), p117-129, 1995.

[2] Board, John, Sandmann G., \& Sutcliffe C. "The Effect of Futures Market Volume on Spot Market Volatility", Journal of Business Finance and Accounting, 28(7) and (8), pp.799-819, 2001.

[3] Bollerslev T., "Generalized Autoregressive Conditional Heteroskedasticity", Journal of Econometrics, 31, pp.307-327, 1986.

[4] Bologna, P., \& Cavallo, L. "Does the introduction of futures effectively reduce spot market volatility? Is the futures effect immediate? Evidence from the Italian stock exchange using GARCH", Applied Financial Economics, 12, pp.183-192, 2002.

[5] Brailsford TJ. , Frino A., Hodgson A.,\& West A. "Stock market automation and the transmission of information between spot and futures markets", Journal Of Multinational Financial Management, 9(3-4), pp.247-264,1999.

[6] Butterworth, D., " The Impact of futures trading on underlying stock index volatility: the case of the FTSE Mid250 contract", Applied Economics Letters, 7,pp.439-442, 2000.

[7] Chan, K. "A Further Analysis of the Lead-lag Relationships between the Cash Market and Stock Index Futures Market", The Review of Financial Studies, 5, pp.123-152, 1992.

[8] Chan, K., Chan, KC., \& Karolyi G.A. "Intraday volatility in the stock index and stock index futures markets", The Review of Financial Studies, 4, pp.657-684, 1991. 
[9] Chatrath, A., Kamtah, R., Chakornpipat, R., \& Ramchander, S. "Lead-lag associations between option trading and cash market volatility", Applied Financial Economics, 5, pp.373-381, 1995.

[10] Chiang, Min-Hsien, Wang, Cheng-Yu. "The impact of futures trading on spot index volatility: evidence for Taiwan index futures", Applied Economics Letters, 9, pp.381-385, 2002

[11] Darrat, A., Rahman, S., \& Zhong, M. "On the Role of Futures Trading in Spot Market Fluctuations: Perpetrator or Volatility or Victim or Regret?”, The Journal of Financial Research, 25 (3), pp.431-444, 2002.

[12] Edwards, F. R. "Futures Trading and Cash Market Volatility: Stock Index and Interest Rate Futures", Journal of Futures Markets, , 8(4), pp.421439, 1988.

[13] Frino A., Walter T., and West A. "The Lead-Lag Relationship between Equities and Stock Index Futures Markets Around Information Releases", Journal of Futures Markets, , 20(5), pp.467-487, 2000.

[14] Gupta O. P., Kumar M. "Impact of Introduction of Index Futures on Stock Market Volatility: Indian Experience", 2002, http://www.pbfea2002.ntu.edu.sg/papers/2070.pdf.

[15] Holmes, Phil. "Spot Price Volatility, Information And Futures Trading: Evidence From A Thinly Traded Market”, Applied Economics Letters, 3, pp.63-66,1996.

[16] Nath, G. C., "Behavior of Stock Market Volatility after Derivatives", 2003, http://www.nse-india.com/content/press/nov2003a.pdf.

[17] Racine MD. , Ackert LF. "Time-Varying Volatility in Canadian and US Stock Index and Index Futures Markets: A Multivariate Analysis, Journal of Financial Research, 23(2), pp.129-144, 2000.

[18] Ryoo, Hyun-Jung, Smith, G. "The Impact of stock index futures on the Korean stock market", Applied Financial Economics, 14, pp.243-251 , 2004.

[19] Shenbagaraman P. “ Do Futures and Options Trading Increase Stock Market Volatility?” NSE Working Papers, Paper No: 60, 2003.

[20] Soydemir G., Petrie G. “ Intraday information transmission between DJIA spot and futures markets", Applied Financial Economics, 13, pp.817-827, 2003.

[21] Yu, Shang-Wu. "Index futures trading and spot price volatility", Applied Economics Letters, 8, pp.183-186, 2001.

[22] Holmes, Applied Economics Letters, July 1995. 